\title{
Research project to determine the effect of free voluntary reading on comprehension
}

\author{
S.I.I. Olën* \& M.P. Machet \\ Department of Information Science, University of South Africa, P.O. Box 392, Pretoria, 0001 Republic of South Africa \\ olensii@alpha.unisa.ac.za\&machemp@alpha.unisa.ac.za
}

Received December 1996; accepted March 1997

\begin{abstract}
The purpose of this research project was to determine the effect of free voluntary reading (FVR) by primary school pupils on their English second-language (ESL) comprehension. An experimental school was provided with a collection of specially selected books and a reading scheme. Then a FVR programme for ESL pupils in standards 2 to 5 was introduced. The control school continued to use only traditional methods of language teaching. Pupils in both schools were given reading comprehension tests at the start of the project and again eight months later. Different statistical tests were carried out on the data. It was found that standard 2, 3 and 4 pupils in the experimental school all made very good overall improvement which was higher than that of the same standards in the control school. There was a significant difference in the improvement of the standard 2 and 4 pupils in the experimental school. Standard 5 pupils showed the least improvement in both schools. It appears that a FVR programme which is introduced early enough in the primary school does effect comprehension more than traditional language teaching methods, but because pupils had problems answering inferential questions, teacher mediation is also an important additional factor. Other findings and recommendations are discussed.
\end{abstract}

\begin{abstract}
Die doel van hierdie navorsingsprojek was om die effek te bepaal van 'n vrywillige leesprogram op die begrip van laerskoolleerlinge met Engels as tweedetaal. 'n Eksperimentele skool is voorsien van 'n versameling spesiaal uitgesoekte boeke en 'n leesskema. Daarna is 'n vrywillige leesprogram vir Engels-tweedetaalleerlinge in standerd 2 tot 5 ingebring. Die kontroleskool het voortgegaan om slegs tradisionele metodes van taalonderrig te gebruik. Leerlinge in beide skole het leesbegripstoetse gedoen aan die begin van die projek en weer agt maande later. Die data is aan verskeie statistiese toetse onderwerp. Daar is bevind dat standerds 2, 3 en 4 in die eksperimentele skool in al die toetse gesamentlik 'n goeie verbetering getoon het wat hoër was as dié van leerlinge in die kontroleskool. Daar was 'n beduidende verskil in die verbetering van standerd 2- en standerd 4-leerlinge in die eksperimentele skool. Standerd 5-leerlinge in beide skole het die minste verbetering getoon. Dit kom voor asof die effek van 'n vrye keuse leesprogram wat vroeg genoeg in die laerskool ingebring word leesbegrip meer bevorder as tradisionele taalonderrigmetodes, maar aangesien leerlinge probleme gehad het om afleibare vrae te beantwoord, is onderwyserbemiddeling ook 'n belangrike bykomende faktor. Ander bevindings en aanbevelings word bespreek.
\end{abstract}

*Author to whom correspondence should be addressed.

In 1995 the South African interim government announced that South Africa would have 11 official languages, with English as the main language. The situation is that in many schools attended by African pupils mother-tongue instruction is given only during the first four years of schooling with English as the only medium of instruction from the fifth year (standard 3) on. Even though English appears fifth on the list of languages most spoken in this country (Zulu, Xhosa, Afrikaans and Tswana have more speakers), it is generally regarded as the language in which proficiency is required for academic and economic advancement. So when pupils enter school they have to master language, but specifically the English language.

Research (Cunningham \& Stanovich 1991:270; Elley 1989, 1991,1992; Elley \& Mangubhai 1983; Krashen 1993) suggests that one of the most successful and economic ways of achieving second-language acquisition and development is through free voluntary reading. In South African schools the teaching of reading has largely focussed on skills, strategies and the processes individual readers acquire and use as they interact with a piece of text. Emphasis is on decoding skills rather than deriving meaning from a piece of text or developing a love of reading. A reading programme based only on skill acquisition can make reading meaningless, and can prevent pupils from becoming proficient readers. Reading is more than an exact, sequential identification of sounds or words, it is a transaction between thought and language, and it is this transaction that leads to comprehension (Chang \& Watson 1988:36). It is only when children realize that the written word contains meaning that it is possible for them to become readers (Vygotsky 1978:52-57).

School-based reading and language programmes provide little opportunity for pupils to read for pleasure or encounter real texts. In spite of teachers paying lip service to the importance of reading, middle to upper elementary school pupils spend little time at home or school reading for pleasure.

From discussions over the past few years with a number of educationalists and teachers it is the researchers' experience that many education authorities and teachers in South Africa are not always convinced of the importance of children reading stories. Many are also not convinced of the value of using free voluntary reading to complement traditional language teaching. Research on the effect of free voluntary reading on language acquisition and development of English second-language (ESL) learners has been done extensively 
abroad, but very little research in this field has been done in South Africa. The researchers thought it would be particularly appropriate to do a research project of this nature at the present time when the education system is being evaluated and restructured. The aim of the research project was to establish the effect of free voluntary reading of English books by pupils in primary school on their English second-language acquisition and comprehension.

\section{Free voluntary reading}

The concept free voluntary reading (FVR) is used by Krashen (1993:x) to refer simply to 'reading because you want to'. As far as he is concerned FVR is one of the most powerful tools available in language education and is the most effective way of achieving proficiency in a second language. Just as spelling and vocabulary are developed in first languages by reading, so too they are developed in second languages. Furthermore, FVR is the most important determinant of vocabulary development, writing and spelling competence and the ability to comprehend and utilize advanced grammatical structures. Other positive consequences of FVR are that it provides much enjoyment, is an important source of knowledge and aids one in defining one's paths in life (Krashen 1995:189).

The International Reading Association issued a statement declaring that literature should be the foundation of the language curriculum and that classroom teachers should be presenting literature-based reading programmes. The belief is that critical thinking skills are developed by considering real problems and issues and not by working through a series of fragmented intellectual exercises (Harris \& Baskin 1989:31). The conscious learning of vocabulary and spelling involves using mental faculties outside the language faculty, which means that only a limited amount of language competence is developed (Krashen 1989:454). Snow and Ninio (1986:121) speak of a contract of literacy and say that the rules of literacy cannot be taught.

'Reading and comprehending texts depend on many tacit "contracts" and "metacontracts" between literate persons concerning the use of books and the meaning of texts - contracts which have very little to do with the ability to decipher a written word'.

A study by Taylor, Frye and Maruyama (1990:360) revealed that time spent reading in school contributed to growth in students' reading achievement. However according to a study by Fielding et al. (cited by Anderson, Wilson \& Fielding 1985:77) reading from books occupies $1 \%$, or less, of children's free time. Simmons (1994:18) maintains that students are completing their schooling without being able to read and Harris and Baskin (1989:29) cite a National Assessment of Educational Progress (NAEP) study which revealed that less than $5 \%$ of 17 -year-olds were functioning at the highest of five possible levels of proficiency. During the last decade students had improved their performance with regard to 'low level skills' like decoding, computing and grammatically correct writing but not with regard to advanced tasks like analyzing, interpreting or assigning differential meanings.

\section{Project population}

The research project was undertaken by a research team at the beginning of 1995 and was completed in June 1996. It would have been desirable to use a number of experimental and control schools in both urban and rural areas, but because of the high costs which this would have involved and also as this was really a pilot project it was decided to limit the scope of the project to a control school and an experimental school in an urban area. In the control school where the total number of pupils was 452 there were 319 ESL pupils. In the experimental school the total number of ESL pupils was 220 out of a total of 1004 pupils. As can be seen from Table 1 there were 139 pupils participating in the study in the experimental school and 105 pupils in the control school. These pupils were in standards 2, 3, 4 and 5 .

The children were all being taught in English even though this was not their home language. To ensure the validity of the survey results it would have been desirable to have classes of equal size and with other variables as similar as possible, but unfortunately this was not possible. For the children in the experimental school it was their first year in an integrated school, because previously they had attended schools in the township which had been for African pupils only. Another difference was that the classes in the control school were smaller than those in the experimental school. There were two classes per standard in the control school which is an English medium school. There was only one English medium class per standard in the experimental school and all the pupils participating in the experiment were in these classes. The school is not a single medium school as there are also a large number of Afrikaans-speaking children being taught through the medium of Afrikaans. Conditions in the control school appeared to be more favourable. However, the control school is in the inner city and on the whole these children are from less advantageous socio-economic circumstances than those from the experimental school where the children are bussed in from a township. To obtain more information on the pupils' backgrounds and factors such as the parents' socio-economic status, the availability of books, periodicals, newspapers, TV et cetera in their homes would necessitate interviews with parents and/or pupils (Machet \& Olën 1997).

Table 1 Pupils participating in research experiment

\begin{tabular}{lccccc}
\hline & Std 2 & Std 3 & Std 4 & Std 5 & Total \\
School & $\mathrm{N}$ & $\mathrm{N}$ & $\mathrm{N}$ & $\mathrm{N}$ & $\mathrm{N}$ \\
\hline Control school & 27 & 24 & 26 & 28 & 105 \\
Experimental school & 39 & 40 & 36 & 24 & 139 \\
\hline Total & 66 & 64 & 62 & 52 & 244 \\
\hline
\end{tabular}




\section{Research experiment}

At the beginning of the experiment pupils in both control and experimental schools were given reading tests to test their comprehension. The tests had been specially developed for ESL readers taking into account cultural variables (Bouwer 1991). The experiment ran for eight months and at the end of this period their reading comprehension was tested again. To allow for natural progression progress of the pupils in the experimental school was measured against the control school which did not have free voluntary reading and had relied on standard language-teaching methods only.

Motivation was an essential factor if the project was to succeed because most of the children come from families that do not have a reading culture. In addition, the children are required to read in a second language. The researchers decided that the best way to motivate the children to read would be to run a competition and award book prizes and $\mathrm{T}$ shirts to the five children in each class that read the most books by the end of the eight-month period; for the researchers to periodically visit the school and read stories to the pupils; and also to hold an interim competition with small prizes. There were no stipulations as to the level of the books so that children who read at a lower level would not be penalized. There was also no stipulation that the books had to come from the classroom collection and a pupil was free to read any book s/he liked as long as it was an English book.

The English teacher ensured that each child had actually read the books that $\mathrm{s} / \mathrm{he}$ claimed to have read by providing a short form which the child had to complete after finishing each book. On the form the child had to give a brief summary (one or two sentences) of the book and then indicate what they particularly liked about the book.

Before starting the project a circular letter was sent to the parents of all the pupils in standards 2 to 5 (4th to 7 th school year) in the experimental school. This letter informed the parents of the nature of the research project, explained the purpose of the project and why the researchers and school staff wanted to encourage reading. The assistance of the parents was sought in motivating and encouraging their children to read as much as possible during the year. Mention was also made of the prizes which would be presented at the end of the year to the pupils who had read the most books.

The schools had previously catered only for white pupils so, although both the experimental and control schools had school libraries, the books in these libraries had few characters with which African ESL readers could identify. Also they catered for children who were English firstlanguage speakers and did not have books that were suitable for ESL readers. As the children participating in the project were unlikely to have a strong motivation to read, it was essential that the books be as accessible and attractive to these children as possible. It was therefore decided that a specially selected collection of books taking into account the children's reading level, cultural background and interests, be provided for these children. This collection was donated to the experimental school by READ (Read Educate and Develop, a non- governmental organization working in the field of literacy and teacher training). A similar collection was donated to the control school after the project was completed. The publishers, Shuter and Shooter, donated a reading scheme containing cards with specially developed stories and questions to the experimental school.

Three teachers in the experimental school worked with the pupils. These pupils had eight periods per week for English of which two were for reading, one for spelling, three for grammar and two for oral work. During the reading periods the teacher and pupils read aloud and discussed the stories. As far as possible the teachers discussed the books with the pupils that they had read at home, but obviously the size of the classes and the limited time did not allow for much scope in this regard. Pupils who had completed their written work were allowed to either read books silently or the cards from the reading scheme during the remainder of the period. Obviously the fast workers were the ones who had the most opportunity for silent reading in the classroom. However, most of the pupils did have books which they took home to read. Pupils in standards 3 and 4 were mostly shy to discuss books with the teacher on an informal basis, but would do this during the periods allocated for oral work when they were given marks for their talks.

In standard 2 there were 11 periods scheduled for English and so their teacher was able to spend two of the three additional periods doing written work and the third period was spent doing silent reading or reading poetry. Standard 2 pupils enjoyed discussing books read at home and their teacher also used this as a theme for oral work.

The general consensus of the teachers was that the parents were pleased with the interest their children had developed in books and that they were satisfied that children were spending some school time on the reading of books and stories. All these teachers believe that reading is the most important factor in second-language learning and comprehension, (one of the reasons that this school was selected to be the experimental school), but a major problem experienced is that the actual school time which could be spent on reading was very limited because the syllabus had to be followed.

\section{Data collection}

In each standard pupils answered four comprehension tests (graded for the specific standard) which each had five multiple-choice questions and five open questions which required written responses. A pupil could score a possible 15 marks per test if all questions were correctly answered. Therefore on four tests the maximum which a pupil could score was 60 marks.

Pupils wrote the four tests in February/March of 1995 and then wrote the same four tests eight months later at the beginning of November 1995. 


\section{Data analysis}

Tests were coded and several statistical analyses were carried out to obtain different perspectives on the data available. Schools were not comparable to start out with. This is reflected by the t-test (independent samples) with pupils from the control and experimental school forming the two independent groups. It would have facilitated interpretation of the results if the results obtained by pupils in both schools had been similar at the start of the project. Other variables may have played a role to 'hide' improvement: smaller classes in control school, quality of teachers, et cetera. No background variables were available such as average for previous year, IQ and home language that could be incorporated in the analysis.

- All missing scores for questions were set to 0 , reflecting that the pupil did not answer those questions (correctly).

- For each pupil in each standard the following calculations were made:

1. total scores for each test (tot1ma-tot4ma) in March

2. total scores for each test (tot1no-tot4no) in November

3. total scores for all four tests (totma) in March

4. total scores for all four tests (totno) in November

A t-test: to determine if the average total scores differ between the control and experimental school. (For each of the four tests for March as well as November and also for the overall score.)

5. difference between November and March scores

(reflecting improvement or not)

that is $\operatorname{diff} 1=\operatorname{tot} 1$ no $-\operatorname{tot} 1 \mathrm{ma} \ldots \ldots \operatorname{diff} 4=\operatorname{tot} 4 \mathrm{no}-\operatorname{tot} 4 \mathrm{ma}$ t-tests (ANOVA): do the schools differ in terms of the above differences of each of the four tests?

multivariate analysis (MANOVA): given the differences diff $1 . .$. diff 4 , is there a significant difference between the control and experimental schools?

- Based on differences a new variable was created (for each test as well as the four tests combined):

If diff $1>0$ then 'improved'

If diffall $<=$ then 'not improved'

cross tabulations: do the schools differ in terms of improved/not improved

- The programme was repeated for open questions (questions 1, 2, 3, 4 and 10 in each test) as well as for the multiple-choice questions (questions 5, 6, 7, 8, 9 in each test)

- Correspondence analysis: association between improvement or not for all standards and both schools

After eight months schooling it is natural for pupils to make progress. From Table 2 it can be seen that most of the pupils in each standard improved, but the percentages of pupils in the experimental school who improved were higher than the percentages of pupils in the control school who improved.

It was necessary, however, to determine whether there was greater improvement overall in the experimental school than in the control school. Table 3 shows that in both schools in all standards there was an improvement in the mean scores obtained overall for the four tests in November. It is also clear that the mean scores in the experimental school were all
Table 2 Numbers of pupils who improved and who did not improve

\begin{tabular}{lcccc}
\hline Std & $\begin{array}{c}\text { Control } \\
\text { school } \\
\text { N improve }\end{array}$ & $\begin{array}{c}\text { Control } \\
\text { school } \\
\text { N not improve }\end{array}$ & $\begin{array}{c}\text { Experimental } \\
\text { school } \\
\text { N improve }\end{array}$ & $\begin{array}{c}\text { Experimental } \\
\text { school } \\
\text { N not improve }\end{array}$ \\
\hline Std 2 & $19(70 \%)$ & $8(30 \%)$ & $35(90 \%)$ & $4(10 \%)$ \\
Std 3 & $22(92 \%)$ & $2(8 \%)$ & $37(92.5 \%)$ & $3(7.5 \%)$ \\
Std 4 & $17(65 \%)$ & $9(35 \%)$ & $31(86 \%)$ & $5(14 \%)$ \\
Std 5 & $18(64 \%)$ & $10(36 \%)$ & $19(79 \%)$ & $5(21 \%)$ \\
\hline
\end{tabular}

Table 3 Overall difference in the mean scores obtained between March and November

\begin{tabular}{lcccc}
\hline School & $\begin{array}{c}\text { Mean score } \\
\text { Std 2 }\end{array}$ & $\begin{array}{c}\text { Mean score } \\
\text { Std 3 }\end{array}$ & $\begin{array}{c}\text { Mean score } \\
\text { Std 4 }\end{array}$ & $\begin{array}{c}\text { Mean score } \\
\text { Std 5 }\end{array}$ \\
\hline Control school & 5.78 & 9.50 & 3.23 & 2.82 \\
Experimental school & 11.31 & 14.65 & 10.11 & 5.25 \\
\hline
\end{tabular}

higher than in the control school. It should, however, be noted that for standard 3 there was considerable improvement in the mean score in both the experimental and the control schools.

\section{T-tests}

T-tests were conducted per standard to determine whether the schools differed in terms of the differences for each of the four tests. Because multiple t-tests were conducted a p-value $<=0.0125$ is considered significant ( $p$-value of 0.05 must be divided by 4 because there were 4 tests).

The results of these t-tests are given below:

\section{Standard 2}

$\begin{array}{llll}\text { Diff1 } & \text { p-value } & 0.9272 & \text { (not significant) } \\ \text { Diff2 } & \text { p-value } & 0.0473 & \text { (not significant) } \\ \text { Diff3 } & \text { p-value } & 0.0117 & \text { (significant) } \\ \text { Diff4 } & \text { p-value } & 0.0631 & \text { (not significant) }\end{array}$

\section{Standard 3}

$\begin{array}{llll}\text { Diff1 } & \text { p-value } & 0.2652 & \text { (not significant) } \\ \text { Diff2 } & \text { p-value } & 0.1623 & \text { (not significant) } \\ \text { Diff3 } & \text { p-value } & 0.0119 & \text { (significant) } \\ \text { Diff4 } & \text { p-value } & 0.3728 & \text { (not significant) }\end{array}$

\section{Standard 4}

$\begin{array}{llll}\text { Diff1 } & \text { p-value } & 0.0093 & \text { (significant) } \\ \text { Diff2 } & \text { p-value } & 0.0507 & \text { (not significant) } \\ \text { Diff3 } & \text { p-value } & 0.3398 & \text { (not significant) } \\ \text { Diff4 } & \text { p-value } & 0.0056 & \text { (significant) }\end{array}$

\section{Standard 5}

$\begin{array}{llll}\text { Diff1 } & \text { p-value } & 0.7240 & \text { (not significant) } \\ \text { Diff2 } & \text { p-value } & 0.1886 & \text { (not significant) } \\ \text { Diff3 } & \text { p-value } & 0.3917 & \text { (not significant) } \\ \text { Diff4 } & \text { p-value } & 0.1185 & \text { (not significant) }\end{array}$




\section{Multivariate analysis (MANOVA)}

MANOVA is a multivariate test to determine for each standard: do the differences in the four tests (diff1 ... diff4) differ overall? The dependent variables are

diff $1=$ difference in test 1 results (tot 1 no - tot $1 \mathrm{ma}$ )

diff $2=$ difference in test 2 results (tot 2 no - tot $2 \mathrm{ma})$

diff $3=$ difference in test 3 results (tot 3 no - tot $3 \mathrm{ma})$

diff $4=$ difference in test 4 results (tot 4 no - tot $4 \mathrm{ma})$

For standard 2 Wilks' Lambda $=2.60481$ with a p-value of 0.0444 (a p-value $<=0.05$ is considered significant).

Overall there is a significant difference between control and experimental schools in terms of the variables diff1, diff2, diff 3 , diff 4 ( $\mathrm{p}$-value $=0.0444)$

For standard 3 Wilks' Lambda $=1.65784$ with a p-value of 0.1719 .

Although there is a significant difference between the two schools in terms of diff3 (third test) the two schools do not differ overall (that is given the four tests diff 1 ... diff4).

For standard 4 Wilks' Lambda $=3.8449$ with a p-value of 0.0078 .

Overall (that is given the four tests diff 1 ... diff4) there is a significant difference between control and experimental schools.

For standard 5 Wilks' Lambda $=1.0235$ with a p-value of 0.4050 .

Overall there is not a significant difference between control and experimental schools in terms of the four tests (that is diff1 ... diff4).

\section{Schools improved/not improved}

Based on differences a new variable was created (for each test as well as the four tests combined):

- If diff $1>0$ then 'improved'

- If diffall $<=$ then 'not improved'

Cross tabulations were made to determine whether the variable diffall differs between the control and experimental schools. Taking the variable diffall $=($ sum of totno - totma $)$ the following results were obtained:

\section{For standard 2 - Diffall p-value of 0.0094}

This indicates a significant difference between the two schools in terms of improved/not improved (a p-value < = 0.05 is considered significant).

\section{For standard 3 - Diffall p-value of 0.0220}

This indicates a significant difference between the two schools in terms of improved/not improved.

\section{For standard 4-Diffall p-value of 0.0008}

This indicates a significant difference between the two schools in terms of improved/not improved.

\section{For standard 5 - Diffall p-value of 0.1571}

This indicates no significant difference between the two schools in terms of improved/not improved.
The graphs in Figures 1, 2, 3 and 4 show the improvement of pupils in each school for each test and overall. Figure 1 shows the improvement for standard 2. For example, one sees that in standard 2 the pupils in the control school scored higher in Test 1 and slightly higher in Test 4, while the pupils in the experimental school achieved higher scores in Tests 2 and 3 and a much higher overall improvement. Figure 2 shows that in standard 3 the experimental school scored much higher than the control school on Test 3, but the overall difference was not very great. Figure 3 shows the scores on the four tests and overall for standard 4. In Figure 4 the scores on the four tests and overall for standard 5 can be seen.

\section{Measures of association}

Cramer's $\mathrm{V}$ ranges from 0 to +1 ; the larger the value of $\mathrm{V}$, the greater the association in the variables. Measures of

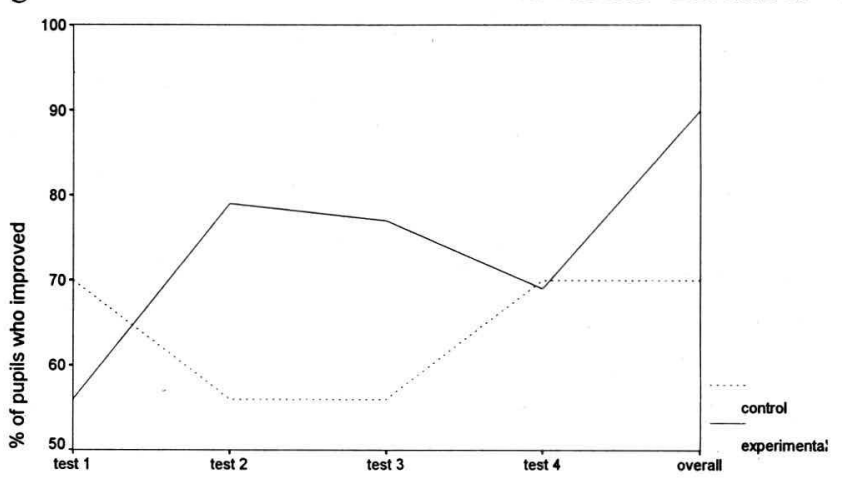

Figure 1 Improvement: Standard 2

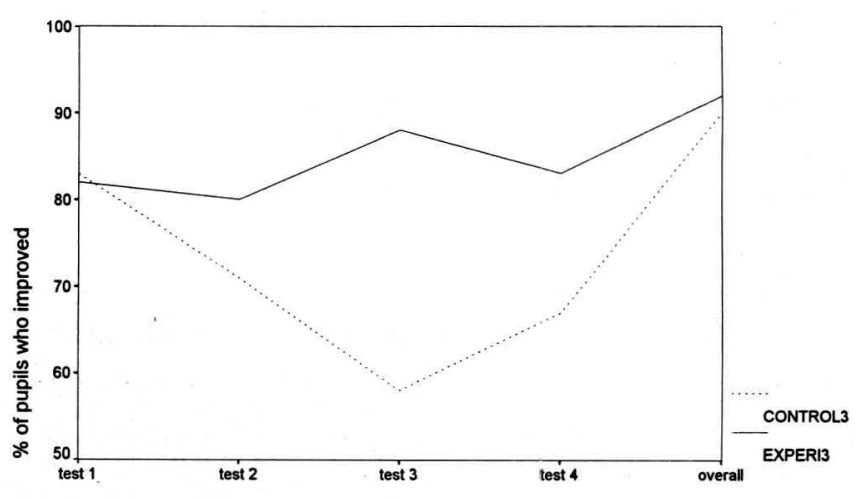

Figure 2 Improvement: Standard 3



Figure 3 Improvement: Standard 4 


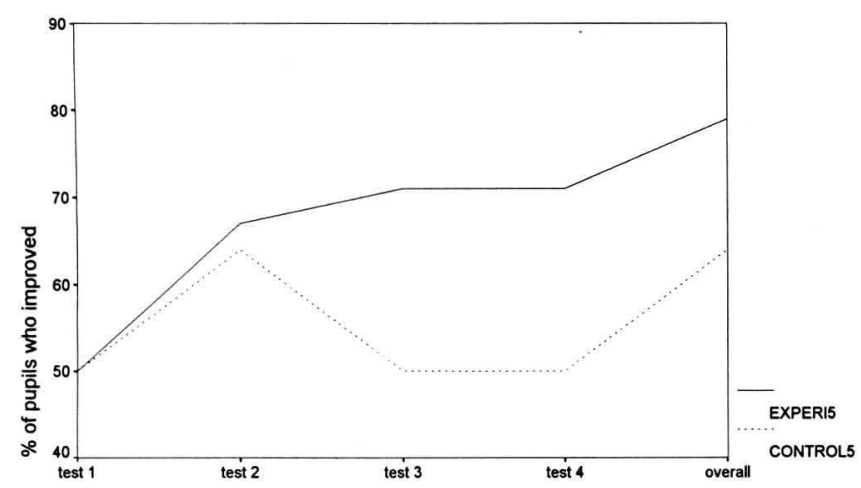

Figure 4 Improvement: Standard 5

association were made to determine whether the school had an effect on the improvement made by the standard. The results given below indicate a weak association between the school and the overall improvement of standard 2 and standard 4 pupils.

Cramer's V:

- for standard 2 diffall 0.247

- for standard 3 diffall 0.015

- for standard 4 diffall 0.245

- for standard 5 diffall 0.164

\section{Open questions and multiple-choice questions}

The data collected on scores for open questions (questions 1 , 2, 3, 4 and 10 in each test) as well as for the multiple-choice questions (questions 5, 6, 7, 8, 9 in each test) showed that there were no differences between overall results obtained for either type of questions. This was done to ensure that pupils were not obtaining higher scores on either the one or the other type of questions.

\section{Correspondence analysis: association between im-} provement or not for all standards and both schools

Correspondence analysis is a multivariate, descriptive method for graphically displaying the rows and columns of a categorical data matrix in a two dimensional space. Correspondence analysis helps to show how variables are related, not just that a relationship exists (Hernon 1994:198). In Figure 5 the correspondence analysis is plotted. Improvement is based on total improvement for all four tests. By projecting the points, standards $(2,3,4$, and 5) and categories (not improved control school; improved control school; not improved experimental school; and improved experimental school) onto the horizontal axis, association is shown. Points which are close together are associated. If points are further apart there is less association. In Figure 5 it can be seen that standard 5 is associated with 'not improved' in both control and experimental schools. 'Improved' experimental school is associated with standard 2 and standard 4 and to a certain extent with standard 3 . Standard 3 is also associated with 'improved' control school.

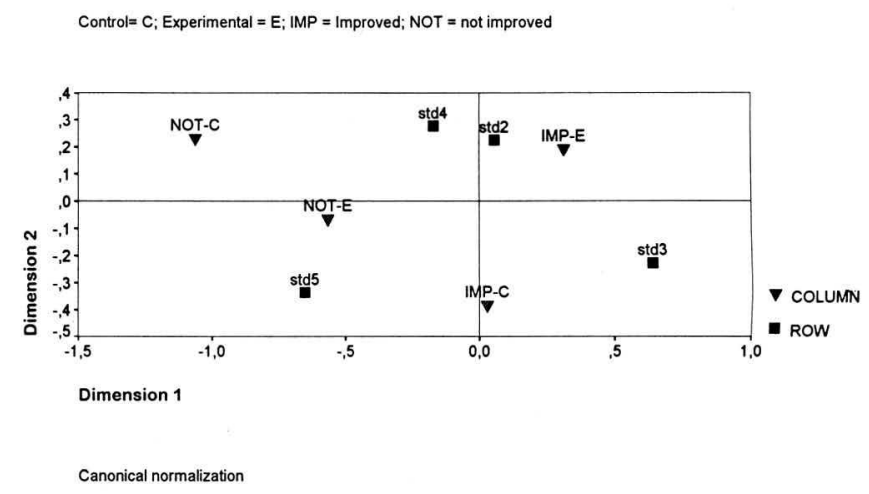

Figure 5 Correspondence analysis plot

\section{Individual pupil scores}

The scores obtained by pupils (identified by pupil number) in the first set of tests (February/March) in each school and in each standard were printed in rank order from top to lowest score. In the next column the scores obtained in the second round of tests (November) were printed and in the last column the difference between the second and first scores. The prize winners in each standard in the experimental school were checked against the results to determine whether there was any correlation between the pupils who read the most and the pupils whose scores improved the most.

All that could be deduced from the data obtained is that the pupils who read the most were either high scorers or made a good improvement, with the one exception in the standard 4 class. It is difficult to correlate the number of books read with individual improvement for a number of reasons. Firstly if a pupil scores high marks the first time then the scope for improvement is limited. Secondly the type of books read are also important. Pupils who read large numbers of books may be concentrating on the easier, shorter books while pupils who improved more are reading longer more challenging books. A final point to bear in mind is that only the names and numbers of the five prize winners in each standard were kept, but many of the pupils who improved their marks substantially may have also read large numbers of books.

\section{Interpretation of the results}

The duration of the project was limited to a period of eight months - more follow-up tests would be required over a longer period to obtain valid data. The fact that the results obtained by the pupils in the two schools differed at the outset must also be taken into consideration. Nevertheless the overall gains made by the pupils in each standard in the experimental school were very good and there was a significant difference in the improvement of the standard 2 and 4 classes in the experimental school. For standards 2, 3 and 4 there was a significant difference between the two schools in terms of the variable improved/not improved. The different tests carried support one another and show that the pupils in the experimental school did better than those in the control school. Although one would expect all pupils to show some improvement over an eight-month period it is difficult, 
without interviews and further research, to understand why some did not improve and why a few actually scored less. One explanation is that some pupils were guessing when it came to multiple-choice questions.

The person responsible for developing the tests, suggests that children need to have a critical level of skills before free voluntary reading will have an effect (Bouwer 1996). If the negative results are among the children of lower ability this could explain the apparent regression. Another factor is that the reading cards supplied by Shuter and Shooter provide reading and language support whereas the books from READ do not. Children who read more cards therefore might have showed a greater improvement, but without careful day-today monitoring of each pupil's reading it is not possible to establish whether there was any correlation. Usually it is the more intelligent children who finish the written work first and these children had more opportunity to do additional reading during class time.

Younger children may be more easily motivated to do free voluntary reading and develop the reading habit - perhaps by standard 5 (or even standard 4) children may be less prepared to spend time on free voluntary reading (especially at home), because these habits have not been formed at an early age. This is probably why the pupils in standards 2 and 3 show the greatest improvement in the mean scores obtained in November.

Reading competitions and Readathons encourage children to read a new book each time and do not encourage children to reread stories they have enjoyed or ensure understanding in other words children will not necessarily have sufficient opportunity to internalize the structure of the story. Some children may be reading a large number of books, but these may be all easy books and other pupils who do not read such large numbers of books may be reading longer more difficult ones.

It appears that pupils experienced fewer problems with the literal questions than with inferential questions in the comprehension tests. Other research has also established that ESL pupils have experienced the greatest difficulty with questions that required some inferences to be made (Pretorius 1995).

\section{Recommendations}

Larger numbers of pupils, at least 50 pupils per standard, should participate so that more appropriate statistical tests can be made. Classes in both schools should not be significantly different at the outset of the project and it would be preferable if the project could be carried out over a longer period of time.

Letters were sent to parents at the start of the project rather than requesting them to come to the school for a meeting. Because of the distance they live from the school it was anticipated that some of them may have had problems with transport. However, it is probably better for researcher to arrange a personal meeting with the parents and to obtain their co-operation and support at the outset. It was difficult for the researchers to control the project. Although the teachers were very co-operative and motivated there was definitely a need for a research assistant to visit the school on a regular basis to discuss pupils' reading with them as teachers do not have sufficient time for this activity. Full records of the different types of reading activities need to be kept as well as monitoring what pupils read. It is possible that pupils who made the most improvement read fewer, but more advanced books, while those who won the competition were reading many but easier works. ESL pupils' reading comprehension cannot be expected to improve solely on the basis of voluntary reading. Teachers will need to do shared and paired reading and spend more time mediating stories. They should ask questions which require pupils to predict events and outcomes or make inferences so that they are better able to understand causal relationships and narrative structures. Teachers should also pay attention to the linking words which help to indicate relationships and cause and effect, words like 'because', 'however', 'therefore' and 'nevertheless'.

The materials donated by READ and Shuter and Shooter fulfilled the requirements of ESL pupils. However, there were only 2.4 books per pupil and one reading scheme which was used by two classes (standards 3 and 4). According to Vermeulen (1992:115), who developed a quantitative model for school libraries in South Africa, there should be 16.9 items per pupil, with approximately 12 of these being books, in a secondary school with $500+$ pupils. No equivalent model has been developed for primary schools in South Africa. Information power (1988:117-118), which provides guidelines for primary schools in developed countries, indicates that libraries with high service in primary schools with fewer than 500 pupils have between 23 and 38 titles per pupil, while those with more than 500 pupils have between 15 and 27 book titles per pupil. This means that primary schools with smaller numbers of pupils actually need more book titles than those with higher pupil enrolments. Likewise the guidelines for Australian school libraries (Learning for the future 1993:23) indicate 34 items per pupil for a school enrolment of 100 pupils, 24 for an enrolment of 400, 21 for 600 and so on. The statement is also made that no school, no matter how small, should have a stock of less than 1000 items. These statistics give an indication of how completely inadequate the number of books available for pupils in the experimental school was. Also an appropriate reading scheme for each class is needed because of the reading and language support provided on each card. It is hoped that Shuter and Shooter will be able to develop a reading scheme for each standard.

In order for a free voluntary reading programme to be successful the English teacher must accept the value of the programme and make time available, at least 10 to 15 minutes per day, for free voluntary reading. This is especially important for those children who come from disadvantaged homes as they are unlikely to have somewhere quiet to read at home, or be given the opportunity. The teacher should also use this time for reading (and not marking or administrative work) as s/he is an important role model for the children. The 
support of the school principal and head of language teaching is also essential as time will need to be taken from language lessons for free voluntary reading and this may be difficult to do without the principal's approval.

A free voluntary reading programme can be used whether reading is taught solely with children's literature or with basal readers as the main source of reading instruction. The voluntary reading programme may use books that children have borrowed from the library, a classroom collection or brought from home.

One of the greatest problems is that a research project of this nature must be carried out within the established educational system. Teachers are required to follow a definite syllabus and therefore time spent on reading activities are of necessity very limited. It is also difficult to involve teachers other than language teachers and ideally one would hope for reading activities to be integrated into all subject teaching. This is obviously also easier to achieve if there is a motivated teacher-librarian in the school and if the education department has a policy to encourage such activities.

\section{Acknowledgement}

The authors wish to acknowledge the assistance they received from Marie Kloppers in carrying out the research project.

\section{References}

Anderson, R.C., Wilson, P.T. \& Fielding, L.G. 1985. Becoming a nation of readers: the report of the Commission on Reading. Washington, DC: National Institute of Education.

Bouwer, A.C. 1991. Content and reading levels for black pupils Std 2-5: guidelines for a reading development kit. Pretoria: Human Sciences Research Council. (Confidential unpublished report).

Bouwer, A.C. 1996. Personal communication, Pretoria, June.

Chang, Y. \& Watson, D.J. 1988. Adaptation of prediction strategies and materials in a Chinese/English bilingual classroom. Reading teacher, 42(1):36-44.

Cunningham, A.E. \& Stanovich, K.E. 1991. Tracking the unique effects of print exposure in children: associations with vocabulary, general knowledge and spelling. Journal of educational psychology, 83(2):264-274.

Elley, W.B. 1989. Vocabulary acquisition from listening to stories. Reading research quarterly, 24(2):174-187.

Elley, W.B. 1991. Acquiring literacy in a second language: the effect of book-based programs. Language learning, 41(3):375-411.

Elley, W.B. 1992. How in the world do students read?: IEA study of reading literacy. Hamburg: Grindeldruck GMBH.
Elley, W.B. \& Mangubhai, F. 1983. The impact of reading on second language learning. Reading research quarterly, 19(1):53-67.

Harris, K. \& Baskin, B. 1989. Toward a culturally literate society. School library journal, 35(12):29-32.

Hernon, P. 1994. Statistics: a component of the research process. Revised edition. Norwood, N.J.: Ablex.

Information power: guidelines for school library media programs. 1988. Chicago: American Association of School Librarians and Association for Educational Communications and Technology.

Krashen, S. 1989. We acquire vocabulary and spelling by reading: additional evidence for the input hypothesis. Modern language journal, 73(4):440-464.

Krashen, S.D. 1993. The power of reading: insights from the research. Englewood: Libraries Unlimited.

Krashen, S.D. 1995. The reading hypothesis, the expanded reading hypothesis and the greatly expanded reading hypothesis. School library media quarterly, 23(3):187-193.

Learning for the future: developing information services in Australian schools. 1993. Carlton, Vic.: Curriculum Corporation, Australian School Library Association and Australian Library and Information Association.

Machet, M.P. \& Olën, S.I.I. 1997. Literacy environment of pupils in urban primary schools. South African journal of library and information science, 65(2):77-84

Olën, S.I.I, Machet, M.P. \& Kloppers, M. 1996. The effect of free voluntary reading by primary school pupils on their English second language. Pretoria: Centre for Library and Information Science, University of South Africa. (Unpublished report).

Pretorius, E.J. 1995. Reading between the lines: causal connectivity, inferences and implicitness in texts. South African journal of linguistics, suppl. 26:3-24.

Simmons, D. 1994. It takes more than a book talk: prereading strategies. Emergency librarian, 21(5): 18-29.

Snow, C.E. \& Ninio, A. 1986. The contracts of literacy: what children learn from learning to read books, in Emergent literacy: writing and reading. ed. W.H. Teale, E. Sulzby. Norwood, NJ: Ablex: 116-138.

Taylor, B.M., Frye, B.J. \& Maruyama, G.M. 1990. Time spent reading and reading growth. American educational research journal, 27(2):351-362.

Vermeulen, W.M. 1992. Quantitative standards for school libraries in South African secondary schools. South African journal of library and information science, 60(2):114-120.

Vygotsky, L.S. 1978. Mind in society: the development of higher psychological processes. Cambridge, Mass.: Harvard University Press. 